\title{
Wangun Visual Concept In Pawukon Figures And Interior Design Contexts
}

\author{
Rahmanu Widayat ${ }^{1}$, Anung B Studyanto ${ }^{2}$ \\ Interior Design Program, Faculty of Arts and Designs, \\ Universitas Sebelas Maret (UNS) Surakarta, Indonesia \\ rahmanuwidayat@staff.uns.ac.id
}

\begin{abstract}
Many of cultural heritages of the past are detting less known by the present generation. One of which is a pawukon figures and their aesthetic values. Pawukon is a Javanese prediction or calculation based on Hindu mythology regarding time and its association with the prediction of human life based on their wuku (time characteristics). There are 30 pawukon figures, from the Wuku Sinta figure to Wuku Watugunung figure accompanied by a picture of their respective deities. Pawukon figures can be found in primbon books or enlarged and displayed in the interiors of Javanese houses. Pawukon figures such as wayang purwa are equipped with figures of buildings or gedhong, figures of weapons, figures of various types of trees, birds and other figures which each have a certain purpose and meaning. The composition of the various elements makes the overall visuals very interesting to be explored regarding the concept of visual, visual aesthetics and meaning. The pawukon figures also needs to be studied aesthetically regarding to their placement in the Javanese home interior and how to develop them to be better known by the present generation. To explore the aesthetics and development of Pawukon figures, the concept of wangun (aesthetic) derived from the Javanese culture was used. The research findings were interesting because the pawukon figures have the wangun elements and wangun visual arrangenments, wangun placement, and the development of the pawukon figures which is related to the concept of wangun and ora wangun (not aesthetic) or aèng (strange). Pawukon figures were made to remind people to be cautious, and their applications and development into interior design were meant to present the atmosphere of Java.
\end{abstract}

Keywords: pawukon figures, interior, development, wangun.

\section{Konsep Wangun Visual Dalam Tokoh Pawukon Dan Konteks Desain Interior}

Banyak warisan budaya masa lalu yang kurang dikenal oleh generasi sekarang. Salah satunya adalah angka-angka pawukon dan nilai-nilai estetika mereka. Pawukon adalah prediksi atau perhitungan Jawa berdasarkan mitologi Hindu tentang waktu dan hubungannya dengan prediksi kehidupan manusia berdasarkan wuku mereka (karakteristik waktu). Ada 30 tokoh pawukon, mulai dari tokoh Wuku Sinta hingga tokoh Wuku Watugunung yang disertai gambar dewa masing-masing. Tokoh-tokoh Pawukon dapat ditemukan di bukubuku primbon atau diperbesar dan dipajang di interior rumah-rumah Jawa. Tokoh Pawukon seperti wayang purwa dilengkapi dengan tokoh-tokoh bangunan atau gedhong, tokoh-tokoh senjata, tokoh berbagai jenis pohon, burung dan tokoh-tokoh lain yang masing-masing memiliki tujuan dan makna tertentu. Komposisi dari berbagai elemen membuat keseluruhan visual sangat menarik untuk dieksplorasi mengenai konsep visual, estetika visual dan makna. Tokoh-tokoh pawukon juga perlu dipelajari secara estetis mengenai penempatannya di interior rumah Jawa dan bagaimana mengembangkannya agar lebih dikenal oleh generasi sekarang. Untuk mengeksplorasi estetika dan perkembangan tokoh Pawukon, konsep wangun (estetika) yang berasal dari budaya Jawa digunakan. Temuan penelitian ini menarik karena tokoh pawukon memiliki unsur-unsur wangun dan wangun pengaturan visual, penempatan wangun, dan pengembangan tokoh-tokoh pawukon yang terkait dengan konsep wangun dan ora wangun (bukan estetika) atau aèng (aneh). Sosok-sosok Pawukon dibuat untuk mengingatkan orang agar berhati-hati, dan aplikasi serta pengembangan mereka ke dalam desain interior dimaksudkan untuk menghadirkan suasana Jawa.

Kata kunci: tokoh pawukon, interior, pembangunan, wangun.

Peer review : 9 - 23 Agust 2018, Accepted : 3 September 2018 


\section{INTRODUCTION}

The study of pawukon figures in the field of art and design is important, considering that traditional art works are less touched by the academic world. The pawukon figures are like the figures in in the zodiac of the Western astrology. Both of them both contain predictions (calculations / péthangan) about human life in accordance with the wuku characters (Javanese zodiac) or star (western astrology). Both of them also have aesthetic figures as wuku symbols or stars that the people have. The difference between pawukon and zodiac is their popularity. The zodiac is popular today and in demand by many people in the world while pawukon is increasingly forgotten and abandoned by its people (Javanese). As a result, the pawukon figures has been increasingly unknown by the Javanese today. Pawukon is also found in Bali. Considering that the Hindu religion, customs and culture are well developed in Bali, pawukon is still sustainable in Bali today. The difference between the Javanese and Balinese pawukon figures lies in the visualization of the $w u k u$ and their deities. In Java, wuku and deity figures are similar to wayang purwa (Javanese leather puppets), the form of pawukon in Bali is similar to Balinese puppets (see: http://www.babadbali.com/ pewarigaan/wuku.htm).

A review on the results of previous studies covers pawukon figures presented in primbon book (Javanese ethnic prediction book) and Almenak Jawa (annually published Javanese book) which so far contains wuku figures, deities of wuku, and figures containing meaning related to character symbols of each wuku. The book of Primbon Djawa Pawukon by Tanojo published in 1973 and Almenak Waspada 1956 present wuku articles including pawukon as one of the guidelines for human life. The 2003 Pawukon book by Sindhunata and Hermanu presented pawukon figures and the origin of pawukon, as an introduction to the pawukon figure exhibition at Bentara Budaya Yogyakarta. In 2013, Hermanu compiled the Pawukon 3000 book which contained Sindhunata's writings regarding pawukon explanations. This book is also an introduction to the pawukon figure exhibition at Bentara Budaya Yogyakarta, especially the work of R.M. Soelardi. Some of these writings have not examined the pawukon figures in terms of aesthetics, its application in interior design, and the possibility of its development to remain known by the present generation. This means that the figures of pawukon have only been presented as illustrative figures and have not been studied in the scientific context of art and design. Further study on pawukon actually relates to the question of "what is pawukon?" How is is pawukon's figures' visuals, aesthetics and meaning? The beauty of the pawukon figures also raise the question of how their application in interior design are? And how is the possibility of developing pawukon figures? The purpose of this study is to explore the aesthetic concept of pawukon figures, which is in line with the writer's current pursuit on local aesthetics in the field of fine arts and design (especially interior design), namely on the concept of wangun (aesthetic). This study is conducted by the author to contribute to the effort to balance the domination of Western aesthetics. The findings of this study on pawukon figures show that pawukon figures have wangun elements and visual arrangements, wangun placement, and that the development of pawukon figures is related to the concept of wangun (aesthetic), ora wangun (not aesthetic) or aèng (strange). This article is arranged sequentially from title, abstract, keywords, introduction, literature and theory, data and methods, results and discussion, and closed with conclusions.

\section{LITERATURE AND THEORY}

This is not the first time that the author applied the concept of wangun to study local visual aesthetics. It is done not to repeat the application of a concept, but to test how far the concept of wangun (aesthetic concept formulated by the author in his dissertation) can be applied in the field of art and design. Western visual aesthetic has a formula that is said to be universal, for example the formal aesthetics. Western visual aesthetics consists of visual elements which are arranged based on visual principles. The visual elements consisting of lines, fields, spaces, colors, and textures, are arranged with the principles of unity, contrast, rhythm, climax, balance and proportion (Djelantik, 2004: 13). This Western aesthetic formulation is often used to analyze the beauty of a local culture, and the results are not necessarily precise. For that reason, to examine the aesthetics of pawukon which is a local culture product (Javanese), the concept of wangun (aesthetic) which is derived from Javanese culture itself or living in the Javanese mindset (kejawèn) is used. Kejawèn by region is the areas affected by cultural influence of Islamic Mataram namely Banyumas, Kedu, Yogyakarta, Surakarta, Madiun, Malang, and Kediri (Kodiran in Koentjaraningrat, ed., 1982: 322). Kejawèn, in the religious context, is the syncretism of native Javanese beliefs, the influence of Hindu-Buddhist teachings and the influence of Islam, while in the context of the supporting community of the Javanese culture, $\mathrm{Ke}$ jawèn consists of wong cilik and priyayi (Suseno, 1991: 37). Wong cilik consists of farmers, labourers and other unskilled workers (Kodiran in Koentjaraningrat, ed., 1982: 337). Priyayi are related to the kingdoms in Java, namely the aristocrates, distinguished figures and courtiers of the palace. The concept of wangun itself in a visual context includes several elements as follows.

1) Wangun visuals consist of wangun elements and the basic rules of wangun arrangement that are generally applicable in Java, 2) the principle of wangun visual placement pattern in the contexts of visual area or space that is generally applicable in Java, 3) angger-angger or wewaler or rules and prohibitions that apply locally or in a region in Java, 4) sacred, 5) meaning in the context of wangun visual and the broader meaning in various contexts. The 
concept outside of wangun (aesthetic) visual and placement is called ora wangun (not aesthetic) or aèng (strange) (Widayat, 2016: 233-285).

Aèng connotes with aneh (strange) or ora njawani (unlike of Javanese origin) which occurs when a work is not guided by the natural foundation of the Javanese mindset. Aeng stands between wangun and ora wangun, because Aeng can sometimes be included in wangun or ora wangun group, or can only be Aeng or aneh, ora njawani. Aeng can become wangun if loved or becoming a trend. Aeng can also become wangun if it has become a habit (pakulinan) or considered normal. And Aeng can become wangun if it gets the legitimacy from the king (in kingdom era). The Aeng that become wangun due to being a habit or legitimacy from the king is outside the natural guidelines of the Javanese mindset which refers to the local angger-angger and wewaler (Widayat, 2016: 216-217).

Wangun visual based on the Javanese mindset (kejawèn) is a visual concept of telu-teluning atunggal and manunggaling kawula Gusti, as well as the placement concept of loro-loroning atunggal, telu-teluning atunggal, papat kéblat kalima pancer, and nawa rupa (Widayat, 2016: 273 -274) The visual of telu-teluning atunggal is three forms in a single vertical unit such as the foot, body, and head. The form of manunggaling kawula Gusti is a form from below (circle, rectangle, octagon and so on) conical upward towards one point above. The concept of wangun placement patterns is loro-loroning atunggal (two figures in one unit), telu-teluning atunggal (three figures in one unit), papat kéblat kalima pancer (five figures in one unit), and nawa rupa (nine figures in one unit) )

In relation with Aeng or strange concept, this concept had been used to explore the development of "Borobudur Chair" design (Widayat and Studyanto, 2018: 160-163). The aeng or strange consept had also been used to study the variety of building decoration in Keraton Surakarta (Widayat and Studyanto, 2018: 335-339).

\section{DATA AND METHODS}

Data on pawukon texts and figures were collected from the following books:

Hermanu, 2013, Pawukon 3000, Yogyakarta: Bentara Budaya.

Sindhunata dan Hermanu, 2003, Pawukon, Yogyakarta: Bentara Budaya.

Tanojo, R., 1972, Primbon Djawa Pawukon, Sala: T.B. Peladjar.

Tanojo, R., without written year of publication, Primbon Sabda Pandita, Surabaya: Trimurti.

Tjakraningrat, K.P.H., 2008, Kitab Primbon Betaljemur Adammakna, Ngayogyakarta Hadiningrat: Soemodidjojo Mahadewa.
Tim Redaksi, 1956, "Wuku.” Almenak Waspada Year III, Ngayogyakarta: Pesat.

Tim Penyusun, 1997, Indonesia Indah Aksara, Jakarta: Yayasan Harapan Kita/BP 3 TMII.

Deity figure wuku on Google Image downloaded on June 152016.

The methods used to study the pawukon figures was technically a set of methods applied in each stages of the study (Muhadjir, 2000: 3), such as the approaches to determine research locations, research forms, data sources, data collection techniques, data validation, and data analysis. Especially regarding data analysis, interactive analysis model was used with three components of data reduction, data presentation, and conclusion drawing or verification which in this study meant the reduction of pawukon figure data, presentation of pawukon figure data, and drawing conclusions on pawukon figures. The reserach activities were carried out in an interactive form with the process of collecting data as a cycle process. The research implementation process was conducted by the researcher who moved among the analysis components while the data collection process was still ongoing (Miles \& Hubermen in Sutopo, 2002: 106).

\section{RESULTS AND DISCUSSIONS}

The Javanese (kejawèn) are colored by mysticism in their lives, namely occult things that cannot be grasped by common sense. Mysticism has been used as a guideline in every form of culture and attitude of the Javanese (de Jong, 1984: 1). One of the Javanese activities related to mysticism is fortune telling. In the context of Javanese occultism and péthangan understanding, there are people who have special talent as fortune tellers called dhukun péthangan. To become dhukun péthangan, most do not obtain their capabilities through formal learning but descended by bloodline or by revelation. To be an expert fortune teller, dukun péthangan must learn universal fortune-telling techniques, such as predicting by calculating based on the location of scattered bones or astrogolomancy, predicting by calculating the scatered chicken intestines that are poured or horuspication, predicting by observing the direction of birds' flight directions and their sounds or ornithomancy and so on. The Javanese fortune-telling understanding uses many of those techniques, and they can be found in the handbooks about occultism and fortune-telling like a primbon. The activity related to Javanese occultism and fortune telling that is very important and widely used is péthangan (Koentjaraningrat, 1994: 421).

Péthangan is a calculation method in order to find a good time and date by taking into account the five pasar days (Javanese day system in addition to the normal days in the lunar calendar which consists of legi, pahing, pon, wagé, kliwon). Important dates are determined on the existing calendar system, this is used by Javanese for various pur- 
poses. One of the existing péthangan is pawukon which contains predictions about human life related to time (Editorial Team, 1961: 47). Pawukon has long developed in Java, according to Prof. Dr. Philip Van Akkeren, a Dutch researcher, explained that the trail of pawukon can be traced from the 10th century, written in charter stones and brass or bronze with ancient Javanese letters. The Charter reports on the use of Javanese pranata mangsa (season provisions) in the form of perlintangan (astrology) and Javanese pawukon alongside with the calendars originating from India. Pawukon at that time had been used for existing kingdoms, and even rural communities in Java had used it long before that time (Sindhunata and Hermanu, 2003: 59).

Pawukon contains predictions about mystical time calculations found in primbon books. These books are not only owned by Dhukun Péthangan or the general public, but also exists in the palace. For example in the Surakarta Palace there is a primbon that contains mysticism and things related to beliefs, such as amulets, prayers, information about a prosperous period, the fate prediction, signs, dream interpretations, fortune telling and so on (Soeratman, 1989: 100). Another example is found in Yogyakarta Palace where there is a primbon that contains certain days and dates considered more suitable than other days for marriage purposes, long trips, building houses and so on. Primbon also contains pawukon. The interesting thing about pawukon is that there are visual forms that are named as a pawukon figures which are given wayang shaped ornament (Tim Penyusun, 1991: 92). Pawukon figures also developed in the form of ancient aristocracy outside the palace walls, such as the Semarang regent Adipati Sura Adimenggala (1765-1839) who served as regent from 1809 to 1822 . Adipati Sura Adimenggala had created a pawukon figure entitled Papakem Watugunung, along with other Javanese manuscripts which were given to Rafles, Crawfurd, and Mackenzie (British officials) at the time of the Dutch East Indies (now Indonesia) to help them study history and culture (Arrangement Team, 1991: 97).

Pawukon figures visually contain aesthetic values, and are applied to the interiors of Javanese houses as aesthetic elements or the items of awe. Currently pawukon figures are also used as aesthetic elements for residential style in contemporary style and interior of public buildings such as hotels, restaurants and so on.

Getting to know pawukon can be started by looking at the story of the wuku occurrence which was freely translated from Javanese language in the following Almenak Waspa$d a$ (Editorial Team, 1958: 62 - 63). The story began when the king Gilingwesi named Prabu Watugunung must die together with his two wives and 27 sons (30 people). This was a punishment because King Watugunung and his son lost the war against Batara Wisnu. Prabu Watugunung's wives, Dewi Sinta and Dewi Landep, then meditated wholeheartedly to ask Batara Guru so that her husband Prabu Watugunung together with his sons were given forgiveness and at the time of death could enter heaven. The requests from Dewi Sinta and Dewi Landep were received by Batara Guru. The spirits of Dewi Sinta, Dewi Landep, Prabu Watugunung with her sons were allowed to enter heaven but not together, but one by one every Sunday or Ngaat every seven days. Dewi Sinta and Dewi Landep asked the deity that the first one to enter Paradise was King Watugunung. But King Watugunung did not want that, instead he asked that those who could enter heaven first were his two wives, and after that his sons. King Watugunung himself asked to enter heaven the last because of his sense of responsibility for the safety of his wife and sons. Prabu Watugung was worried that if his spirit entered heaven first and the deity in power reneged on the promise then the fate of his wives and sons became unclear. King Watugunung's request was approved by the deities and even received praise.

The story above sets the background for $w u k u$ calculation known as pasaran minggon in which each week has seven days starting from Sunday to Saturday, while the following Sunday has changed to a new different wuku. The number of wuku is 30 based on the story of King Watugunung with his two wives and 27 sons. So that in one year, there are 210 days of pethangan pawukon, namely the pasaran minggon multiplied by the number of wuku called sa dor or saubengan (one cycle). Each person can be determined for his/her wuku. Details in determining a person's wuku are not discussed in this paper, but among others it can be looked up in the book written by Ki Hudoyo Doyodipura entitled Horoskop Jawa Misteri Pranata Mangsa (Doyodipura, 1995; xiii). An easy way to determine a person's wuku today is by accessing the website kidemang. com, then click Weton Wuku and continue to fill in the date, month, and year of birth, then the wuku and the characters will be shown (see: http://ki-demang.com/almanak /? do $=$ character $)$.

Pawukon has 30 character figures which start from number one Wuku Sinta up to number thirty Wuku Watugunung, containing the character of each wuku who was brought from birth, depicted through the characteristics of the deities. The visual conditions are symbolized as buildings, temples, banners, the state of objects in the form of weapons such as kris, spears and so on. Other symbols are manifested in the characteristics of trees, birds, water conditions, feet submerged in water, or hands that support things. All of them show certain characteristics and visualized in the form of figures or paintings of Javanese tradition taking the idioms of wayang purwa. Each Wuku figures faces his/her own deity. The wuku figure is always presented with a sitting position, while the deities are depicted with a standing position and some are seated but with a higher level, and some sit on top of a water vase. The buildings are visualized as found in the Gunungan 
Gapuran of wayang purwa with two doors or other building forms. The depiction of the temple is made with a pile of stones like temples in Central Java, the more upward the smaller the arched door. Trees, birds, distilled weapons (ornamented) so that they blend with other figure elements. There are also those elements that are expressed in words or dicondro (metaphorically expressed) like Indra Nestapa (Lord Indra who is very sad), the sun's rays, the visible mountains, fruitful trees, lintang karahinan (stars that have been preceded by day) and others which have specific meanings and intentions. The 30 figures of wuku characters can be looked up in the book of Primbon Betaljemur Adammakna (Tjakraningrat, 2008: 82 - 88).

The relationship between pawukon figures and interior design, especially in Javanese home interiors, can be seen through the number of Javanese people who use pawukon figures as aesthetic elements for their home interiors. The purpose of using pawukon figures is to add beauty and as a symbol of homeowners' wuku. Pawukon figures are made with a relatively large size so it is suitable to be placed on the interior walls of the house. With regard to interior design, in the context of design process, the pawukon figures function as an aesthetic element of the interior, which is integrated into the design process from the beginning. In connection with the notion of interior design as a form of a building inner side, the pawukon figures can be assessed for aesthetics and its placement pattern in interior design. One example of the beauty of pawukon figure and its explanation is presented in the following picture of $W u k u$ Wayang (see figure 1).

The Wuku Wayang, with Bumi Batara Sri Deity and Cempaka wood element, is liked by many of those with great influence. The bird is the jungle chicken which is loved by the nobility, with the body of Sri which is noble and beautiful, staring at pasu (water vase) in sincere and devoted manner, sitting on tranquil water, avoiding sharp object, having a smooth character at first but getting complicated at the end. Wayang = pradangga pati, it means making clear of everything/giving understanding, with misfortune possibility of being killed, suggested Alms: a kendit goat (alive), pure jaddah (sticky rice cakewithout any mixture in the making), and the prayer should be attended by 40 people (surrounded by blessings). The Kala (Batara Kala) is above facing downward, for 7 days the person with this wuku is prohibited to climb. Wayang mega lumaku patine andaka wana (The Noble and polite Wayang that defeats insolent character).

Pawukon figures when studied with the concept of wangun can be explained as follows. The pawukon visuals have the main and supporting visual forms. The main visual form is the forms of wuku and their deities, while the supporting visual forms are the appearance of important symbols of the wuku figures. An example of pawukon figure from Wuku Wayang figure above is the main visual form of Wuku Wayang (outer structure) and its deity Batari Sri (outer structure). Both figures have lower, middle and upper visual elements or legs, bodies, and heads arranged vertically called wangun visual of telu-teluning atunggal (inner structure). The Wuku Wayang and Batari Sri deity in the picture are placed with the pattern of wuku figure on the left side and the deity figure on the right (the viewer's point of view) or the elements of left and right are face to face (kiwa-tengen adu arep) which is in accordance with the wangun placement pattern of loro-loroning atunggal (two aestheticts in one unit). Associated with the wangun element deity figure, especially those in the form of animals such as Batara Anantaboga (outer structure) have horizontal structure; the deity figures have the shape of head, body and tail or front, middle and back with a horizontal arrangement. The Batara Anantaboga structure is called wangun visual of telu-teluning atunggal (three aesthetics in one unit) as "inner structure". The concept of placing wangun loro-loroning atunggal between the human wuku and their deities is found in 30 pawukon figures. Particularly for Wuku Watugunung, even though there are two deities (Batara Anantaboga and Batari Nagagini), the concept of placement is still loro-loroning atunggal, because the the left-right arrangement is facing each other in a single unit or arrangement of kiwa-tengen adu arep. The supporting visual elements in pawukon figures are placed in a different pattern compared to the placement of the main characters. The supporting visual forms are based on the meaning contained in each form. When a pawukon figure with a large enough size is displayed on the interior wall of a house, the wangun placement pattern of the wife's pawukon figure is displayed on the left, while the husband's pawukon figure is displayed on the right (left and right position seen from the viewer's/homeowner's point of view).

Angger-angger (rules) and wewaler (prohibition) on pawukon figures are applicable locally such as the style of the Kingdom era of Surakarta and Yogyakarta. Angger-angger and wewaler in this case are the guidelines on the visualization of human $w u k u$, namely by the sitting on the floor position, while the deity figure is standing. There are times when the deities are sitting, but their positions are still higher than the human wuku, or sitting on a higher seat. Another rule about the position of the human wuku on the left while the position of the deity is on the right (seen from the viewer's or creator's point of view). The position of the deity on the right because the deity has a higher position compared to humans so that he/she is placed to the right of the drawing field. A prohibition related to the pawukon figure plaement is that the deity's position may not be switched with the human wuku position. The pawukon figure as a symbol of human life with wuku and the deity has a visually sacred value because it is related to the prediction of the good and bad fortunes of the human life itself. When people want to be safe they must be able to meet certain requirements, and when the requirements are 
violated they will get bad fortune.

Pawukon figures and their contents contain philosophical, sociological and spiritual meanings. The philosophical meaning is related to the teachings of that the Javanese must be careful in living their lives, this is in accordance with the Javanese proverb yitno yuwono mati lena kena which means those who are cautious will be safe and those who are careless will face misfortune (MH, 2010: 209). Pawukon figures are sociologically easier to remember by the Javanese (kejawèn) communities who support the traditional Javanese culture because the figures are visualized with the idioms of wayang purwa that are close to their lives. Pawukon figures are spiritually related to the meaning of human wuku in accordance with his/her deity or the belief that humans are influenced by the character of their respective deities. The visual analysis of pawukon figures based on wangun concept is presented in the following figure (see figure 2 and 3 ).

The findings of wangun pawukon figures were: 1) the main visual characters have wangun visual element of telu-teluning atunggal (three aesthetics in one unit) arranged vertically, 2) the main visual characters of deities in the form of animals consist of head, body and tail forms arranged vertically and horizontally, 3 ) the main visual characters are placed with the wangun placement pattern of loro-loroning atunggal adu arep (two aesthetics in one unit facing each other), 4) the supporting visual forms are placed with the placement pattern in accordance with their meaning, 5) the placement of pawukon figures on the wall of the house interior is the husband's pawukon symbol on the right and the wife's symbol on the left, 6) the pawukon figures have sacred values, 7) Pawukon figures contain philosophical meaning (life guidance), sociological (with visualization of wayang purwa which is closer to the life of the Javanese people), and spiritual values (believing in god's character).

The figures outside of the wangun (aesthetic) concept is considered ora wangun (not aesthetic) or aèng or strange. One of the examples of pawukon figure is Wuku Kulawu number 28 which was published in Almenak Waspada in 1956. Wuku Kuwalu with its god Batara Sadana in a two-dimensional form are combined with some figures like buildings, floors, water, trees, birds, spears and their sheath ) made in three dimensions. The shape of the building in pawukon figuresis generally inspired by the appearance of Javanese house roofs, but the presentation of the building in this $w u k u$ is in Roman style complete with traps (cripedoma), doric poles, and pediment forms (triangular wall construction), and is equipped with dome (domes). This particular pawukon figure with its two-dimensional wuku presentation and deity characters feels aeng (strange) with supporting shapes of three-dimensional forms, and that the building's shape is not Javanese but Roman-style (see figure 4).
There are pawukon figures that appear wangun at the first glance, but when observed, they are actually aeng or ora wangun. This aeng figure will become wangun if it is favored or received legitimacy from certain authorities (the king in the kingdom era). There are three aeng pawukon figures created by R.M. Soelardi from Surakarta who also actively drew wayang from 1930 to 1960 . The three figures are Wuku Tolu, Wuku Kuningan, and Wuku Langkir. These three pieces of Pawukon figures are not in a position of facing their deities like pawukon figures in general. The pictures of Wuku Tolu, Kuningan, and Langkir are facing the opposite direction from the positions of their deities namely Batara Bayu, Batara Indra, and Batara Kala. This is the aeng element which raises the question of why did the wuku figures do not face their deities and turned my back instead? Is this as a form of creativity or development by the creator that steps out of the wangun visual and classical standard? Or is this the intended application of the aeng concepts? These questions need to be explored further. The development of pawukon figures with wangun concept can actually be conducted by means of ngowahi rupa or changing the basic visual of wuku, deity and supporting figures of pawukon, and not changing the position of $w u k u$ and the deity that face each other (see figure 5).

The application of pawukon figures in interior design emphasizes more on the presence of the Javanese atmosphere, especially the interiors that are built nowadays. Pawukon figures are presented in hotel interiors using a Javanese theme (lobby, restaurant, meeting room and bedroom). This is an effort and development conducted by interior designers to present Javanese cultural artifacts as an aesthetic element that has been widely forgotten by today's generations. The purpose of this application is to participate in preserving Javanese culture in the context of modern life. Pawukon figures for residential interiors are rarely applied, because many people today no longer know what Pawukon figures are. It is actually very interesting when Javanese people participate in preserving their culture by displaying pawukon figures in the interior of their homes. The application of pawukon figures, in addition to presenting the Javanese atmosphere, is also a form of appreciation for the works of the ancestors. Participation in maintaining the cultural heritage should be pursued or else the Javanese must not be surprised or feel cheated when the culture is developed by other nations. Moreover, pawukon figures can describe the character of the house's residents. Technically, the installation of pawukon in the interior should use wangun concept; that is the wuku figure of the husband on the right and the wife on the left and displayed in the main room of the house. Right and left installation in wangun concept is seen from the homeowners' point of view and not from the direction of the viewers/guests. Pawukon figures based on children's wuku in the family can be displayed in the family room or in the bedroom of each child. Its function is to remind the characters of each of them based on their wuku so that it can be used as a guide in 
living their lives safely.

\section{CONCLUSION}

Pawukon figures have the main elements of wuku characters and their deities. The $w u k u$ and deities are in the form of wayang purwa or wayang kulit (Javanese leather puppet). Both figures have wangun visual forms of legs, body, and head structure or having the lower, middle, and upper elements arranged vertically in one unit. This arrangement is in accordance with wangun concept telu-teluning atunggal (inner structure). The visually wangun pawukon figures is the existence of two main characters namely wuku (left) and deity (right) (from the viewers' point of views) and facing each other horizontally. The left and right positions face each other - in accordance with wangun placement concept of loro-loroning atunggal (inner structure) arranged in $a d u$ arep (face to face) setting. Deity w $u k u$ characters with visualized in animal form such as Batara Anantaboga have head, body and tail structures or front, middle and back arranged in variations vertically and horizontally. These three elements become a unity that is in accordance with the concept of telu-teluning atunggal. There are a black and white pawukon figures printed on the primbon book. And there are also pawukon figures which are colored similarly to the color of the wayang purwa in the primbon book that is written and given figures directly.

Pawukon figures contain philosophical meanings related to the teachings of Javanese people way of life to be cautious and safe, because if they are careless, they will face harms. Sociologically the pawukon figures are actually easier to remember by the Javanese people (kejawèn) because it is tangible like the wayang purwa that is close to their lives. Pawukon figures are spiritually interpreted as human wuku in accordance with his/her deity or the belief that humans are influenced by the character of their respective deities. The development of pawukon figures with wangun concept can be realized by not changing the "inner structure", both the form of figures (telu-teluning atunggal) and the character placement in the pawukon figures (loro-loroning atunggal) which is adu arep or face to face and not facing backward to the opposite directions. The application of pawukon in contemporary interior design can be applied to the public building interiorss that require the presence of a Javanese atmosphere. The application of pawukon figures at home is recommended for the application of the husband's and wife's wuku. The pawukon figures are displayed on the wall of the main room in pairs, the symbol of the husband on the right and the symbol of the wife on the left. Left and right positions for home applicaion are seen from the homeowners' point of view, while pawukon figures for children can be applied in their bedroom or family room.

\section{ACKNOWLEDGEMENT}

The authors would like to express their gratitude to Prof. Dr. Dharsono, M.Sn., Prof. Ir. Eko Budihardjo, M.Sc. (late), Prof. Drs. S.P. Gustami, S.U., and Dr. Titis S. Pitana, S.T., M. Trop. Arch., who have supported the arrangement of wangun concept related to the writer's dissertation.

\section{REFERENCES}

de Jong, S, 1984, Salah Satu Sikap Hidup Orang Jawa, Yogyakarta: Yayasan Kanisius.

Djelantik, A. A. A., 2004, Estetika Sebuah Pengantar, Bandung: Masyarakat Seni Pertunjukan Indonesia bekerja sama dengan Arti.

Hermanu, 2013, Pawukon 3000, Yogyakarta: Bentara Budaya.

Ki Hudoyo Doyodipura, 1995, Horoskop Jawa Misteri Pranata Mangsa, Semarang: Penerbit Dahara Prize.

Kodiran, 1982, "Kebudayaan Jawa" dalam Manusia dan Kebudayaan di Indonesia, Koentjaraningrat, ed., Jakarta: Djambatan, hal. 322 s.d. 345.

Koentjaraningrat, 1994, Kebudayaan Jawa, Jakarta: Penerbit Balai Pustaka.

MH, Yana, 2010, Falsafah dan Pandangan Hidup Orang Jawa, Yogyakarta: Absolut.

Muhadjir, Noeng, 2000, Metodologi Penelitian Kualitatif, Yogyakarta: Rake Sarasin.

Sindhunata dan Hermanu, 2003, Pawukon, Yogyakarta: Bentara Budaya.

Soeratman, Darsiti, 1989, Kehidupan Dunia Kraton Surakarta 1830 - 1939, Yogyakarta : Penerbit Taman Siswa.

Suseno, Franz Magnis, 1991, Etika Jawa Sebuah Analisa Falsafi tentang Kebijaksanaan Hidup Jawa. Jakarta: PT Gramedia Jakarta.

Sutopo, H.B., Metode Penelitian Kualitatif. Surakarta: Sebelas Maret University Press, 2002.

Tanojo, R., 1972, Primbon Djawa Pawukon, Sala: T.B. Peladjar.

Tanojo, R., tanpa angka tahun, Primbon Sabda Pandita, Surabaya: Trimurti.

Tim Penyusun, 1991, Katalog Surat Emas Budaya Tulis Indonesia, Jakarta: Yayasan Lontar. 
Tim Penyusun, 1997, Indonesia Indah Aksara, Jakarta: Yayasan Harapan Kita/BP 3 TMII.

Tim Redaksi, 1956, “Wuku.” Almenak Waspada Tahun keIII, Ngayogyakarta: Pesat.

Tim Redaksi, 1958, "Wuku.” Almenak Waspada Tahun keV. Ngayogyakarta: Pesat.

Tim Redaksi, 1961, “Wuku.” Almenak Waspada Tahun keVIII. Ngayogyakarta: Pesat.

Tjakraningrat, K.P.H., 2008, Kitab Primbon Betaljemur Adammakna, Ngayogyakarta Hadiningrat: Soemodidjojo Mahadewa.

Widayat, Rahmanu, 2016, Estetika Barang Kagunan Interior Dalem Ageng di Rumah Kapangéranan Keraton Surakarta, Disertasi Program Pascasarjana Institut Seni Indonesia (ISI) Surakarta.

Widayat, Rahmanu and Studyanto, Anung B., 2018. Exploration of Design Development Borobudur Chair with The Aèng Method (strange), Proceedings of the 4th Bandung Creative Movement International Conference on Creative Industries 2017 (4th BCM 2017), Amsterdam: Atlantis Press, page $160-163$.

Widayat, Rahmanu and Studyanto, Anung B., 2018. Aèng Visual Ornament of The Surakarta Palace's Building, Proceedings of the 4th Bandung Creative Movement International Conference on Creative Industries 2017 (4th BCM 2017), Amsterdam: Atlantis Press, page 335-339.

Website

http://ki-demang.com/almanak/?do=watak

http://www.anomsuryaputra.id/2015/01/wayang-dan-simbol-wuku-astrologi.html

http://www.babadbali.com/pewarigaan/wuku.htm

\section{LIST OF FIGURE}

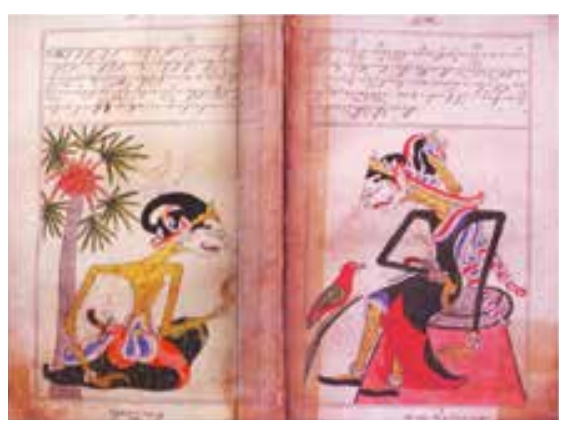

Figure 1. Wuku Wayang (Image source: scan result of Indonesia Indah Aksara book, Creator Team, 1997: 42, 43)

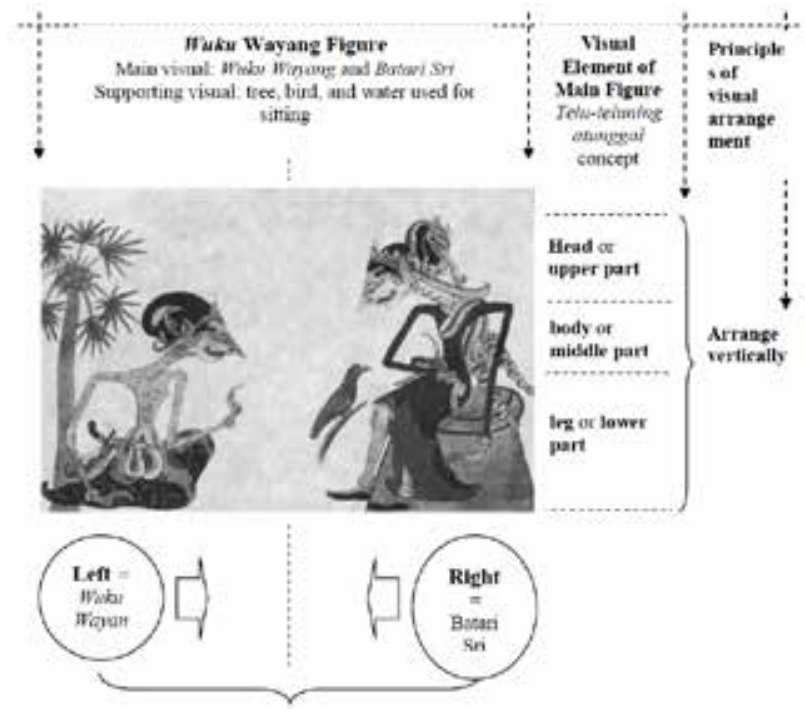

Main visual placement: using wangun loro-loroning atunggal pattern of Wuku Wayang on the left and Batari Sri on the right arranged horizontaly left and right face to face or adu arep kiwa-tengen

Supporting Visual elements: trees, birds, occupied water related to the appearance and arrangement based on special rules (angger-angger) in accordance with the symbolic meaning contained in the supporting visuals of the pawukon figure or based on the creator's creation

Figure 2. The main visual elements of Wuku Wayang and Batari Sri with placement pattern of wangun loro-loroning atunggal arranged horizontaly or as one unit facing each other on the right and left or adu arep kiwa-tengen (Source of pawukon figure: scan of Pawukon book by Sindhunata dan Hermanu, 2003: 55)

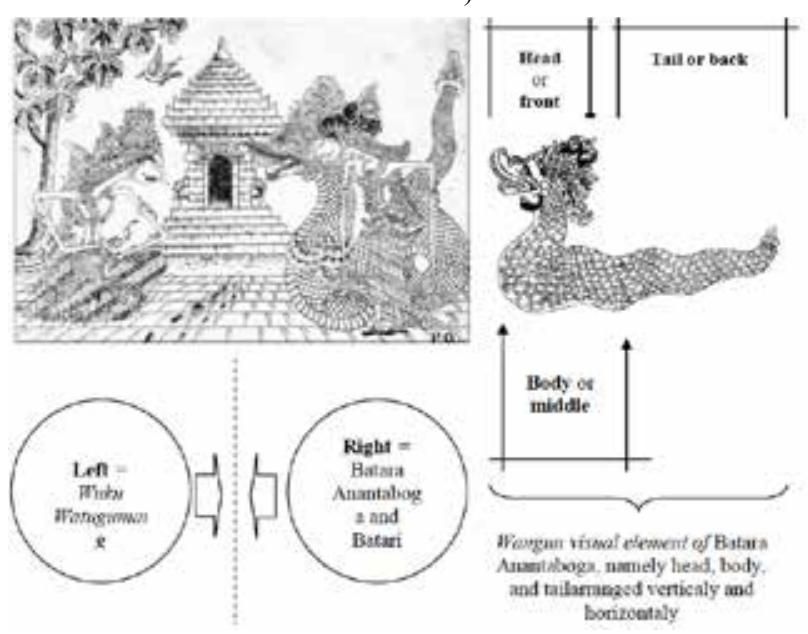

Figure 3. wangun main character placement of loro-loroning atunggal arranged horizontaly or as one unit between Wuku

Watugunung with the deity Batara Anantaboga and Batari Nagagini, facing each other on the right and left or adu arep kiwa-tengen. The visual of Batara Anantaboga (outer structure) has visual elements namely front, middle, and back or head, body and tail in accordance with the telu-teluning atunggal (inner structure), arranged in a vertical and horizontal combination (source of pawukon figures: scan Almenak Waspada, 1956: 121) 


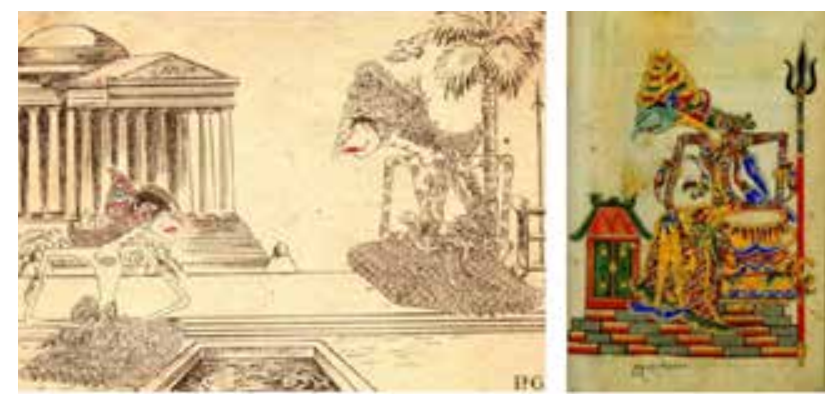

Figure 4. Wuku Kuwalu, pawukon aèng visual, is a wuku and the deity two dimensional shape (wangun visual of loro-loroning atunggal) combined with supporting figures in three dimensional shape, and the building shape is not of Javanese origin but of Roman, this figure is presented in Alamenak Waspada published in 1955 in Yogyakarta (Left figure source: scan Almenak Waspada, 1956: 117). This figure can be compared to house visual of Wuku Kuwalu using Surakarta style with Javanese style building (Right figure source: http://www.anomsuryaputra.id/2015/01/wayang-dan-simbol-wuku-astrologi.html : downloaded September, 12, 2016)
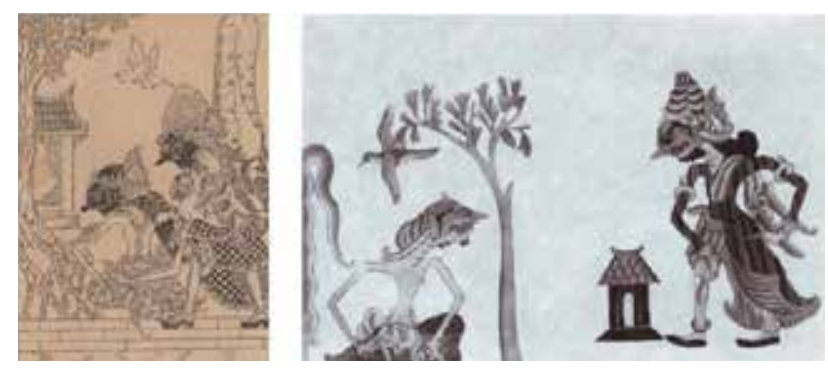

Figure 5. Pawukon visual of Wuku Tolu by R.M. Soelardi is categorized as "aèng" because Wuku Tolu does not face its deity Batara Bayu (Left figure source, foto source of Pawukon 3000 book, by Hermanu, 2013: 72). Visual comparison of pawukon wangun, which is Wuku Tolu facing Batara Bayu (Right figure source: scan of Pawukon book, by Sindhunata and Hermanu, 2003: 33) 